\title{
Low Pension Participation among Minority Workers in the U.S.
}

\author{
Sung David Chun ${ }^{1}$, Wei Sun $^{2} \&$ Yeojun Caleb Chun ${ }^{3}$ \\ ${ }^{1}$ Associate Professor, Mercy College of Ohio, Toledo, Ohio, USA \\ ${ }^{2}$ CEO of North Systems Technology, South Bend, Indiana, USA \\ ${ }^{3}$ Marketing Systems Analyst, HCR ManorCare, Toledo, Ohio, USA \\ Correspondence: Sung David Chun, Associate Professor of Sociology, Mercy College of Ohio, 2221 Madison Ave, \\ Toledo, OH 43604, USA. Tel: 419-251-1791. E-mail: chun1000@gmail.com
}

Received: August 12, 2015

Accepted: September 5, $2015 \quad$ Online Published: September 15, 2015

doi:10.5430/ijfr.v6n4p134

URL: http://dx.doi.org/10.5430/ijfr.v6n4p134

\begin{abstract}
The present study documents and models Latinos' pension participation likelihood relative to non-Hispanic Whites and non-Hispanic Blacks. Multivariate regression methods were used to analyze data from the 1996 Survey of Income and Program Participation (SIPP) panel which was collected from April 1996 to March 2000. Results indicate that Hispanics and non-Hispanic Blacks were significantly less likely to participate in pension plans (defined contributions plans such as $401 \mathrm{k}$ and $403 \mathrm{~b}$ ) than non-Hispanic White Americans. In multivariate analyses where demographic background, industry and occupation characteristics, availability of affordable pension plans, and eligibility statuses were specified, there was still a significant net racial effect in predicting the DC pension participation likelihood.
\end{abstract}

Keywords: minorities, Hispanics, African Americans, pension, retirement

\section{Introduction}

The improvement of the living standards of older Americans over the past thirty years has been a stunning victory for U.S social policy. Real incomes of the elderly doubled and poverty rates plunged from over $30 \%$ in the early 1960 s to under $10 \%$ in 2010 (U.S. Bureau of the Census, 2011). Despite these accomplishments for the current elderly, the future economic prospects of this cohort are not bright, mainly due to structural change of the employer pension system.

Over the past twenty years, the retirement savings structure has shifted from the traditional defined benefit (hereafter DB) plans with employer contributions to a diverse set of more individualized savings plans known as defined contributions (hereafter DC) plans (e.g. 401k and 403b) with tax shelter, cash surrender or loan, and portability features that appeal to the short-term needs of workers. In other words, the risk and responsibility for retirement savings have transferred from employer to employee, and firms use DC pension plans to lower their overall pension contributions per worker (Ghilarducci and Sun, 2006). The 1980s and 1990s were a period of great pension upheaval: the share of workers covered by a 401(k) plan jumped from $25.8 \%$ in 1988 to $67.1 \%$ in 2006 (Copeland, 2009). Although DC plans offer increased flexibility and choice to diverse workforces, the problem they impose is that employees do not have long-term promises to protect their retirement income in the way DB plans historically have done.

More importantly, the transition from DB to DC plans results in low pension participation rates and low retirement savings for Americans, resulting in financial insecurity for the new cohort of elderly (Even and Macpherson, 2007; Farkas and O'Rand, 1998). This financial insecurity for American elders will threaten the economic well-being of the new elder cohort, especially when considering the increased life expectancy of the average American. Furthermore, the shift from DB to DC plans is expected to simultaneously increase the level and inequality of pension wealth at retirement. Evidence suggests that the shift to DC plans may result in less pension wealth at retirement for low-income workers, women, and minorities (Even and Macpherson, 2007).

In particular, when discussing Latino retirement income and wealth, it is critical to note the increase in the US racial gap in retirement income and wealth (Choudhury, 2001/2002; Kochhar, 2004; Conley and Glauber, 2008). Latinos' lower pension participation will likely continue to broaden this racial gap. Only few studies on pension participation have included Latinos in their analyses as a separate racial category, and very minimal research has been conducted 
on the Latino labor force's preparation for retirement. Thus, the present study examined the retirement behavior of Latino workers, focusing on behavior differences from that of non-Hispanic Whites and Blacks. Suggestions on reforming the current security system and reducing racial disparities in pension participation rates will be provided. .

\section{Literature Review}

Pioneer studies concerned with pension participation did not differentiate between non-Hispanic Whites, non-Hispanic Blacks, and Latinos (Copeland, 2002; Gonyea, 2007; Halperin and Munnell, 1999; Hinz and Turner, 1998; Shuey and O'Rand, 2004). Additionally, despite successful efforts in identifying Latinos, some research has focused more on the impact of socioeconomic characteristics on pension coverage than directly assessing the racial and ethnic effect on pension coverage (Ariel Education Initiative and Hewit Associates, 2009; Even and Macpherson, 1999).

Previous studies have made progress in finding structural constraints causing low pension participation of Latinos relative to non-Hispanic Whites (Chen, 2002; Perez, 1998). These studies identified three reasons as to why Latino workers may not be covered in an employer pension plan. First, Latino workers are less likely to be in circumstances conducive to employee benefit coverage such as health insurance and pension plans (Santos and Seiz, 2000). Pension coverage is higher among high earners; those with union contracts; those who work for larger employers; employees in specific industries including manufacturing, government, transportation, communication, and utilities; and those who hold professional and managerial occupations (Bernstein, 2002; Purcell, 2002). Latinos are under-represented in all of these pension-friendly situations. The second crucial reason for low pension participation of Latinos is that they are less likely to be eligible to participate in the plan offered at their workplaces. Employer attachment is the most important distinction explaining the differences in pension coverage among Latinos and other workers (Perez, 1998). Latinos have worked for their present employers for shorter years than non-Hispanic Whites, and thereby do not qualify for the plans offered by their employers. The third reason for low pension participation of Latinos is that they voluntarily choose not to participate in their employers plan, even though they may be eligible. Although this last reason may not be the strongest explanation of why Latino workers tend not to have pension plans, it is nonetheless worrisome as more employers are turning to voluntary-type, tax-deferred savings plans as their main pension offering. Because Latinos are more likely to choose not to be covered even when they have the opportunity, the nation's dramatic shift to voluntary DC plans may more critically impact Latino retirees than non-Hispanic White retirees.

\section{Research Questions}

Latinos have low pension coverage due to a low sponsorship rate, a high ineligibility rate, and a high rate of voluntary pension plan opts out. These are well-known and obvious findings in the literature. However, what is not known is whether Latinos' low pension participation rate can be attributed solely to occupation or industry related characteristics. If this is the case, solutions for Latinos' low pension participation will be related to placing Latinos in better working conditions. However, if Latinos do not participate in a pension plan despite an equivalent level of pension benefits, the factors explaining Latinos' low pension participation must be identified outside their employment settings. The solutions would likely be associated with voluntary non-employment related factors. In this vein, the central research question of the present study is whether Latinos participate in DC pension plans as much as non-Hispanic Whites when they are employed in settings where DC pension plans are not only offered but also are within their eligibility. This issue is significant for understanding the well-being of Latinos, but it is also important for providing a broader perspective on the nature of immigrants and the integration of their offspring into contemporary American society. Thus, the present study's overarching concern is assessing whether Latinos are still less likely to participate in DC pension plan than non-Hispanic Whites, controlling for sponsorship, eligibility, personal demographic background, socioeconomic status, and job characteristics.

\section{Data and Measures}

Data was drawn from the 1996 Survey of Income and Program Participation (SIPP), because of its comparatively large sample size and inclusion of details on the race and immigration status of respondents. The SIPP is a longitudinal survey, i.e., it follows a panel of households over several years. The 1996 SIPP panel was interviewed from April 1996 to March 2000. Particularly, the 1996 SIPP Wave 7 ("Retirement Expectations and Pension Plan Coverage") is a unique data source because for the first and only time to date, it included detailed questions on types of pension plans, pension benefits, and pension contributions. Most importantly, it asked employees whether their employers sponsored pension plans, whether employees participated, and why they did not participate when a pension plan was offered. To correlate this information with demographic characteristics, SIPP Wave 7 was merged with 1996 SIPP core data and 1996 SIPP Wave 2 data, which contains general demographic information from respondents and immigration history. Another advantage is that SIPP datasets include information about Latino subgroups. But, it is unfortunate that low sample size of non-Mexican subjects did not permit us to investigate a more nuanced examination of the variation of 
pension participation among Latino subgroups. Nonetheless, this study overcomes the significant data limitations faced by previous scholars (Rogers, 1982; Even and Macpherson, 1999; Santos and Seitz, 2000).

The dependent variable was an individual's decision to participate in DC pension plans. DC pension participation was coded $0=$ not participate, $1=$ participate. Our principal independent categorization, race, was represented by three dummy variables for Latinos, non-Hispanic Whites, and non-Hispanic Blacks. Workers in the "other" race/ethnicity category were excluded. In addition, non-Hispanic Whites were not specified in the models (coded $0=$ non-Hispanic Whites), meaning that the odds for Latino workers and non-Hispanic Blacks should be compared to that of non-Hispanic White workers.

Major predictors of personal demographic background, socio-economic status, and job characteristics could affect the likelihood of DC pension plan participation. Previous studies have found that age, income, education, marriage, and gender are significantly associated with pension participation. Workers in larger firms and the manufacture industry had higher average participation rates. In addition, workers with the labor union membership and with a long year of tenure, white collar, and full time workers had significantly higher participation rates (Hinz and Turner, 1998; Bassett, Fleming, and Rodrigues, 1998). For this reason, we estimated the likelihood of pension participation controlling for all of these variables. However; union membership, full-time versus part-time, and white versus blue collar status were dropped from the analyses in the interest of parsimony, because the case numbers of part-time, blue collar, and union member workers were minimal and their inclusion did not significantly enhance the predictive power of any of the models presented here.

Several measures to assess the effects of personal demographic background were included with age as a continuous variable. Initially, the squared age variable was specified. It came up with negative sign of squared age variable which means that the age effect becomes negative at a certain age - 93 years old in our case. The total age effect was still significant after considering this minimal negative age effect. Thus, this squared age variable was not included in our current models. Gender and nativity were measured as dummy variables. Female and foreign-born workers were excluded categories. With regard to marital status, married workers with spouse was an excluded category with married workers without spouse, widowed, divorced, or never married workers being controlled. For socio-economic status, education and income were included. Categorical-variable indicators for educational attainment: less than high school, high school graduate (excluded category), some college, four-year degree, and post college education were used. Natural logarithm of earning was also controlled. The influence of job and industry related background is captured with a continuous variable for the number of years in the current job and with two dummy variables: firm size (100 employees or higher versus less than 100 employees) and the industry variable (trade, manufacture (excluded category), service, and other industry). These characteristics are all associated with both pension eligibility and coverage (Bernstein, 2002). Although pension eligibility standards apply equally to every racial and ethnic group, a disadvantaged status in the labor market makes Latino workers less eligible for employer-sponsored pension plans in comparison to non-Hispanic White and Black workers.

The sample for descriptive comparison (Table 1) and regression analysis (Table 2) is restricted to those respondents with the following socio-demographic characteristics and pension types. The sample includes only those respondents aged 21 to 64 as ERISA (Employee Retirement Income Security Act of 1974) requires pension participants to be at least 21 years old. In addition, the present sample includes only full time workers in non-agriculture private sectors whose employers provide DC pension plans for which the workers are also eligible. The present sample excludes individuals who have defined benefits plans (DB) since all eligible workers are automatically enrolled into DB plans, eliminating the factor of intentional non-participation. As noted above, retirement planning has been largely relegated to individuals, and therefore, it is efficient to observe individuals' pension behavioral choice when focusing on DC plan participants. Although the sample also includes self-employed individuals, it was not feasible to control for self-employment because SIPP did not include "self-employment" as a separate background variable. According to the 2000 U.S. Census Summary File 4, 7\% of non-Hispanic Whites, 3\% of non-Hispanic Blacks, and 5\% of Hispanic workers were self-employed. Unfortunately, it was not possible to measure how this difference in self-employment rate among the three groups affected their DC pension participation estimation.

The treatment of missing data was another key issue. It is possible that missing data introduced a conservative (or negative) bias toward estimation. However, in the present sample, no evidence of missing cases introducing bias was observed, which supports the random distribution of our samples. For most variables, an insignificantly small percentage of cases contained missing data, and thus, we followed the standard of handling these cases via listwise deletion. Additionally, the dataset also excluded some individuals who had zero income when other variables indicated that they were, in fact, working. 
The resulting restricted sample enabled the examination of whether or not Latinos' low pension participation was simply attributable to involuntary or structural constraints. By eliminating workers whose employers did not provide DC pension plan and who were not eligible, our equation removed the likelihood that the estimates were upwardly biased. In practical terms, the present study was able to directly examine whether or not the difference in DC pension participation rates disappear, everything else being equal.

Sampling weights which adjusted for no response, attrition, and differential probabilities of selection into the sample were used only for descriptive analysis. Logistic analyses of large datasets are typically performed on unweighted data since even slight differences can be deemed statistically significant when the sample size is in the thousands. Consequently, all of our multivariate models were performed on unweighted data.

\section{Descriptive Statistics}

As noted earlier, three reasons stand out in explaining the low pension participation of Latinos. The present analysis of the 1996 SIPP panel confirms the explanatory power of these three reasons. First, Figure 1 shows that employer sponsorship rate was only $41 \%$ of all Latino workers aged 21 to 64 in the private sector, whereas the employer sponsorship rate for both non-Hispanic Whites and non-Hispanic Blacks was identically 59\%, 18\% higher than that for Latinos. Ineligibility rate, the second principal reason for Latinos' low pension participation was $24 \%$ for both Latino and non-Hispanic Black workers aged 21 to 64 in the private sector whose employers offered a pension plan, whereas the rate for non-Hispanic Whites was $18 \%$.

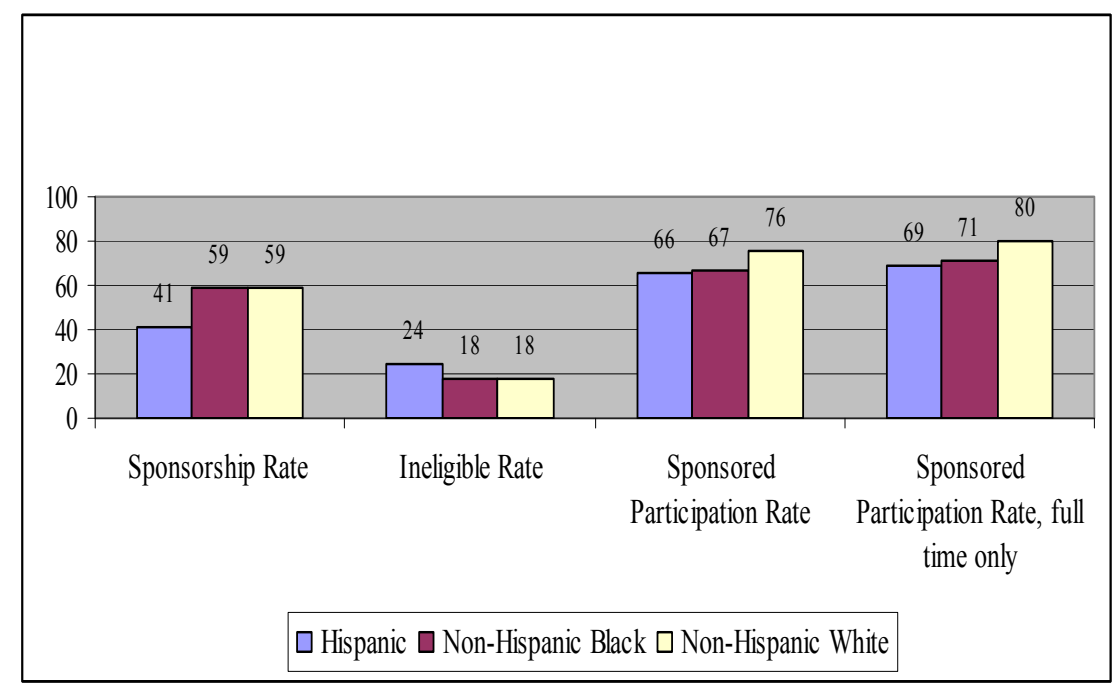

Figure 1. Pension sponsorship, ineligibility, and participation by race, all workers in private sector aged 21-64 (\%)

The third and fourth bars of Figure 1 highlight the third explanation for Latinos' low pension participation rate, the voluntary opt out rate. While $66 \%$ and $67 \%$ of Latino and non-Hispanic Black workers aged 21 to 64 in the private sector voluntarily chose to participate in their employer's plan when eligible, this rate for non-Hispanic Whites was $76 \%$. When considering only full time workers aged 21 to 64 in the private sector, the disparity in voluntary DC pension participation rate was still significant. The rate was $69 \%$ for Latino full time workers, $71 \%$ for non-Hispanic Black full time workers, and $80 \%$ for non-Hispanic White full time workers. Thus, the current research was concerned with the possible effects of demographics, education, income rate, and employment related background variables with the hope of decreasing the racial difference in DC pension participation likelihood.

Understandably, Table 1 shows that Latinos were younger than non-Hispanic workers so that they had a higher percentage of "never married" workers. There were a greater percentage of foreign born workers among Latinos relative to non-Hispanic Whites. Latinos possessed a lower education attainment than non-Hispanic Whites. Latinos' average earning $(\$ 27,684)$ was slightly higher than that of non-Hispanic Blacks $(\$ 27,048)$ but much lower than that of non-Hispanic Whites $(\$ 36,960)$. Years of working for current employer were significantly shorter among Latino workers than among non-Hispanic Blacks and non-Hispanic Whites. Additionally, Latinos were more likely to work in the trade or service industry. 
Table 1. Summary Statistics of Variables, full time workers in private sector aged 21-64

\begin{tabular}{|c|c|c|c|c|}
\hline & Latinos $^{\dagger}$ & & $\begin{array}{l}\text { Non-Hispanic } \\
\text { Blacks }\end{array}$ & $\begin{array}{l}\text { Non-Hispanic } \\
\text { Whites }\end{array}$ \\
\hline \multicolumn{5}{|l|}{ Demographic Variables } \\
\hline Average Age (years) & 37.7 & & 40 & 40.5 \\
\hline Male & $57 \%$ & & $44 \%$ & $55 \%$ \\
\hline Married spouse present(reference) & $62 \%$ & & $42 \%$ & $68 \%$ \\
\hline Married no spouse & $2 \%$ & $* * *$ & $2 \%$ & $0 \%$ \\
\hline Widowed & $1 \%$ & & $3 \%$ & $1 \%$ \\
\hline Divorced & $13 \%$ & & $23 \%$ & $14 \%$ \\
\hline Never married & $23 \%$ & $* * *$ & $29 \%$ & $16 \%$ \\
\hline U.S. born & $61 \%$ & $* * *$ & $95 \%$ & $97 \%$ \\
\hline \multicolumn{5}{|l|}{ Class Variables } \\
\hline Less than high school & $28 \%$ & $* * *$ & $14 \%$ & $7 \%$ \\
\hline High School (reference) & $25 \%$ & & $31 \%$ & $27 \%$ \\
\hline Some college education & $34 \%$ & & $36 \%$ & $30 \%$ \\
\hline College graduate & $9 \%$ & $* * *$ & $13 \%$ & $24 \%$ \\
\hline Post college education & $4 \%$ & $* * *$ & $6 \%$ & $12 \%$ \\
\hline Average Earnings & $\$ 27,684$ & $* * *$ & $\$ 27,048$ & $\$ 36,960$ \\
\hline \multicolumn{5}{|l|}{ Job Related Variables } \\
\hline Tenure at Current Job (years) & 7.8 & $* * *$ & 8.9 & 9.1 \\
\hline Employed in firm with $100+$ empl. & $65 \%$ & & $71 \%$ & $66 \%$ \\
\hline Manufacturing (reference) & $24 \%$ & & $22 \%$ & $26 \%$ \\
\hline Trade industry & $20 \%$ & $*$ & $14 \%$ & $16 \%$ \\
\hline Services industry & $15 \%$ & $*$ & $13 \%$ & $13 \%$ \\
\hline Other industry & $41 \%$ & & $51 \%$ & $45 \%$ \\
\hline Number of Cases & 491 & & 670 & 6,877 \\
\hline
\end{tabular}

\section{Logistic Regression Results}

In this section, logistic regression analysis was used to assess whether participation rate differences in DC pension plan between Latinos, non-Hispanic Whites, and Non-Hispanic Blacks can be explained by differences in personal demographic characteristics, socioeconomic status, and job characteristics. The estimation of the likelihood of pension participation is found in Table 2. Comparisons of model fit statistics show that the addition of sociodemographic variables (in Model 2) enhanced the predictive power of the base model (Model 1). Likewise, the addition of employment related variables (in Model 3) significantly enhanced the predictive power of the socio demographic model (Model 2). However, taken together, these results demonstrate that race had a strong and independent estimated net effect on DC pension participation likelihood, even while controlling for a wide array of covariates.

Several specific findings in Table 2 merit some discussion. The first base model in Table 2 includes only the bivariate effects of race on DC pension participation. All of the observed Latino/non-Hispanic White gap and non-Hispanic Black/non-Hispanic White gap were statistically significant from 0 at the $0.1 \% \alpha$ level. The likelihood of participation in a DC pension plan was decreased for Latino workers by $50.7 \%$ (exp -.708=.493) and for non-Hispanic Blacks workers by $52.1 \%$ (exp $-.736=.479)$, compared to non-Hispanic White workers. Participation 
rate logits were conducted for three sets of independent variables in the next three models. When personal characteristic variables and socioeconomic status variables were added to the base model (Model 2), the differences between Latinos' and non-Hispanic Whites' participation rates were significantly reduced but were still statistically significant. Being Latinos and non-Hispanic Blacks decreased the odds of participation in a DC pension plan by $29.1 \%$ and by $35.3 \%$, respectively.

The final full model produced the decreased odds by $29.6 \%$ for Latino workers and by $37.3 \%$ for non-Hispanic Black workers. Interestingly, the magnitude of these net effects of race was not substantially decreased between Model 2 and 3 with the addition of employment related controls. For the most part, the estimated net effects of covariates on the likelihood in DC pension participation produced a general pattern of selection consistent with findings from previous research (Chen, 2002; Perez, 1998). Life course variables and employment related variables in Model 3 impinge on DC pension participation likelihood. Several patterns are especially noteworthy. Age difference was statistically significant, with participation rates increasing by $1.7 \%$ per year age. Interestingly unlike previous research (Hardy and Shuey, 2000), the participation rate difference between male and female workers was not statistically significant. However, the participation rate difference between married and single workers was significant, indicating that the odds of DC pension participation were lower to never married singles by $20.3 \%$ and to divorced workers by $20.7 \%$ than married workers with spouse present, regardless of race and Latino origin. The most unexpected finding in Model 3 was related to the effect of nativity on DC pension participation likelihood. Understandably, U.S.-born workers are more likely than immigrant workers to be assimilated into the American financial system. Thus, they are more likely to possess the skills needed to navigate the American financial system (Cobb-Clark and Hildebrand, 2006a and 2006b). In contrast, immigrants typically maintain stronger ties to their countries of origin and/or live in ethnic enclaves where ethnic culture is reproduced. If this general pattern was the case in the present sample, the present results should show that U.S.-born workers were significantly more likely to choose to participate in DC pension plan, holding all else equal. However, unexpected results were obtained, such that the difference was not statistically significant. This outcome suggests studying structural and cultural variation in the dynamics surrounding native workers' pension participation opportunities and decisions.

As for the estimated net effects of socioeconomic status on DC pension participation likelihood, Model 3 indicates that education had a significantly positive effect on participation rates. Education, measured as high school completion $(=0)$, increased the likelihood of participation. The more educated respondents were more likely to participate in a DC pension plan. Post college degree holders were slightly more than twice as likely to be participants in a DC pension plan (exp. $7103=2.035$ ) than high school graduates. Workers with a bachelor degree were 1.69 times more likely to be participants. The earning was also positively correlated to the DC pension participation rate. Structural factors generally affected pension participation patterns. The likelihood of participation was increased significantly among workers with longer years of job tenure, with participation rates increasing by $7.7 \%$ for those with one year job tenure. However, those employed in firms of 100 employees or more were at lower risks for non-participation but not at a statistically significant level. Finally, as expected, the trade and service industries both decreased the likelihood of participation by $28.0 \%$ and $26.4 \%$, respectively, when compared to the manufacture industry.

Several contingency models were conducted. Looking at only native born workers, interestingly enough, there were still significant differences in $\mathrm{D} / \mathrm{C}$ participation rate between Latinos and non-Hispanic Whites. What this finding means regarding U.S.-born Latinos' integration or assimilation into mainstream society needs to be investigated further. Separate analyses were conducted for college graduates and for non-college graduates. Yet, the findings remain the same. In an additional analysis, the possibility of a selection effect was examined using two other ways. At this time, the result offers an admittedly weak test for selection effects. First, the present analyses used those between the ages of 21 and 44 and those between the ages of 45 and 65, separately. This limits the sample to only those for whom other effects would be most salient since older interviewees presumably have had more chances to participate in DC pension plans. In the full model for those aged 21 to 44, the same pattern as with the full sample emerged but racial effect became insignificant in the full model for those aged 44 and 65 . The second additional test replicated the present analysis using those above median earning and those below median earning, separately. The results for this test were quite interesting. In low-earning sample, the same pattern as with the full sample emerged but racial effect only for Latinos disappeared in the full model for the above median makers. This may lend further support to the argument that a selection effect is to some extent responsible for racial effect. 
Table 2. Logistic regression predicting participation in a DC pension by race

(21- to 64-year olds full time workers in private sector)

\begin{tabular}{|c|c|c|c|c|c|c|c|c|c|}
\hline & \multicolumn{3}{|c|}{ Model 1} & \multicolumn{3}{|c|}{ Model 2} & \multicolumn{3}{|c|}{ Model 3} \\
\hline & Coeffi. & S.E. & & Coeffi. & S.E. & & Coeffi. & S.E. & \\
\hline Hispanic & -0.708 & 0.110 & $* * *$ & -0.345 & 0.137 & $* *$ & -0.352 & 0.138 & ** \\
\hline Black & -0.737 & 0.095 & $* * *$ & -0.436 & 0.109 & $* * *$ & -0.473 & 0.111 & $* * *$ \\
\hline Age & & & & 0.036 & 0.004 & $* * *$ & 0.017 & 0.004 & $* * *$ \\
\hline Male & & & & 0.138 & 0.072 & \# & 0.112 & 0.074 & \\
\hline Married no spouse & & & & -0.557 & 0.350 & & -0.464 & 0.354 & \\
\hline Widowed & & & & -0.312 & 0.285 & & -0.249 & 0.289 & \\
\hline Divorced & & & & -0.274 & 0.099 & \# & -0.232 & 0.100 & * \\
\hline Never married & & & & -0.264 & 0.091 & \# & -0.227 & 0.092 & $*$ \\
\hline Native & & & & 0.155 & 0.152 & & 0.106 & 0.153 & \\
\hline Less than high school & & & & -0.157 & 0.128 & & -0.131 & 0.130 & \\
\hline Some college educati & & & & 0.226 & 0.085 & ** & 0.290 & 0.086 & $* * *$ \\
\hline College graduate & & & & 0.412 & 0.104 & $* * *$ & 0.525 & 0.107 & $* * *$ \\
\hline Post college educatio & & & & 0.579 & 0.159 & $* * *$ & 0.710 & 0.163 & $* * *$ \\
\hline Log earning & & & & 0.591 & 0.053 & $* * *$ & 0.497 & 0.054 & $* * *$ \\
\hline Job tenure & & & & & & & 0.073 & 0.007 & $* * *$ \\
\hline Firm size & & & & & & & 0.018 & 0.075 & \\
\hline Trade industry & & & & & & & -0.329 & 0.108 & ** \\
\hline Services industry & & & & & & & -0.309 & 0.121 & $*$ \\
\hline Other industry & & & & & & & -0.146 & 0.094 & \\
\hline Constant & 1.818 & 0.035 & $* * *$ & -4.456 & 0.439 & $* * *$ & -4.808 & 0.431 & $* * *$ \\
\hline -2 Log likelihood & 6,874 & & & 5,556 & & & 5,409 & & \\
\hline Number of Cases & 8,0 & & & 8,0 & & & 8,0 & & \\
\hline
\end{tabular}

\section{Summary and Limitations of the Study}

The present study models Latinos' pension participation likelihood relative to non-Hispanic Whites and non-Hispanic Blacks. Multivariate regression result indicates that Hispanics and non-Hispanic Blacks were significantly less likely to participate in pension plans (defined contributions plans such as $401 \mathrm{k}$ and $403 \mathrm{~b}$ ) than non-Hispanic White Americans. In multivariate analyses where demographic background, industry and occupation characteristics, availability of affordable pension plans, and eligibility statuses were specified, there was still a significant net racial effect in predicting the DC pension participation likelihood.

This study has several limitations. Because our data set does not include all relevant variables, different pension participation decisions across groups in response to marriage and pregnancy are not fully taken into account. The endogeneity of labor participation and employment status is not explicitly modeled in our study. Thus, one of the important questions for future research is why Latinos are less likely than non-Hispanic whites to participate in the labor market and to be employed. 


\section{References}

Ariel Education Initiative \& Hewit Associates. (2009). 401(k) Plans in living color: A study of 401(k) savings disparities across racial and ethnic groups. Lincolnshire, IL: Hewitt Associates.

Bassett, W. F., Fleming, M. J., \& Rodrigues, A. P. (1998). How Workers Use 401(k) Plans: The Participation, Contribution, and Withdrawal Decisions. National Tax Journal, 51, 263-289. http://dx.doi.org/10.2139/ssrn.940656

Bernstein, D. (2002). Fringe Benefits and Small Businesses: Evidence from the Federal Reserve Board Small Business Survey. Applied Economics, 34, 2063-2067. http://dx.doi.org/10.1080/00036840210126205

Chen, Y. P. (2002). Employee Preferences as a Factor in Pension Participation by Minority Workers. Boston, Mass.: Gerontology Institute, University of Massachusetts Boston.

Choudhury, S. (2001/2002). Racial and Ethnic Differences in Wealth and Asset Choices. Social Security Bulletin, 64(4). Washington, D.C.: Social Security Administration.

Cobb-Clark, D. A., \& Hildebrand, V. A. (2006a). The Wealth and Asset Holdings of U.S.-born and Foreign-born Households: Evidence from SIPP Data. Review of Income and Wealth, 52, 17-42. http://dx.doi.org/10.1111/j.1475-4991.2006.00174.x

Cobb-Clark, D. A., \& Hildebrand, V. A. (2006b). The Portfolio Choices of Hispanic Couples. Social Science Quarterly, 87, 1344-1363. Doi: http://dx.doi.org/10.1111/j.1540-6237.2006.00431.x

Conley, D., \& Glauber, R. (2008). Wealth Mobility and Volatility in Black and White. Washington, D.C.:The Center for American Progress.

Copeland, C. (2002). An Analysis of the Retirement and Pension Plan Coverage: Topical Module of SIPP. March EBRI Issue Brief. Washington, D.C.: Employee Benefit Research Institute.

Copeland, C. (2003). Employment-based Retirement and Pension Participation: Geographic Differences and Trends. April EBRI Issue Brief. Washington, D.C.: Employee Benefit Research Institute.

Copeland, C. (2009). Retirement Plan Participation: Survey of Income and Program Participation (SIPP) Data, 2006. February EBRI Note, 30(2), Washington, D.C.: Employee Benefit Research Institute.

Even, W., \& Macpherson, D. (1999). Defined Contribution Plans and the Distribution of Pension Wealth. Industrial Relation, 46, 551-581. http://dx.doi.org/10.1111/j.1468-232x.2007.00480.x

Even, W., \& Macpherson, D. (2007). Racial and Ethnic Differences in Pension Coverage and Benefit Levels. Report submitted to the Department of Labor. Washington, D.C.: U.S. Department of Labor.

Farkas, J. I., \& O'Rand, A. M. (1998). The Pension Mix for Women in Middle and Late Life: The Changing Employment Relationship. Social Forces, 76, 1007-1032. http://dx.doi.org/10.2307/3005701

General Accounting Office. (2000). Characteristics of Persons in the Labor Force without Pension Coverage and Benefit Levels. Washington, D.C.: United States General Accounting Office.

Ghilarducci, T., \& Sun, W. (2006). How Defined Contribution Plans and 401(k)s Affect Employer Pension Costs 1981-1998. Journal of Pension Economics and Finance, 5, 175-196. http://dx.doi.org/10.1017/s1474747205002386

Gonyea, J. G. (2007). Improving the Retirement Prospects of Lower-Wage Workers in a Defined-Contribution World. Families in Society-The Journal of Contemporary Social Services, 88, 453-462. http://dx.doi.org/10.1606/1044-3894.3655

Halperin, D., \& Munnell, A. (1999). How the Pension System Should Be Reformed. Brookings Institution Conference Paper on ERISA after 25 Years: A Framework for Evaluating Pension Reform. Washington, D.C.: Brookings Institution Conference.

Hardy, M. A., \& Shuey, K. (2000). Pension Decisions in a Changing Economy: Gender, Structure, and Choice. Journal of Gerontology Series B-Psychological Sciences and Social Sciences, 55, S271-S277. http://dx.doi.org/10.1093/geronb/55.5.s271

Hinz, R. P., \& Turner, J. A. (1998). Pension Coverage Initiatives: Why Don't Workers Participate? In Olive S. Mitchell and Sylvester J. Schieber (Eds.), Living with Defined Contribution Plans. Philadelphia, PA: The Pension Research Council, The Wharton School of the University of Pennsylvania and University of 
Pennsylvania Press.

Kochhar, R. (2004). The Wealth of Hispanic Households: 1996 to 2002. Washington, D.C.: Pew Hispanic Center.

Munnell, A. H., \& Sullivan, C. (2009). 401(k) Plans and Race, Number 9-24. Chestnut Hill, MA: Center for Retirement Research at Boston College.

Munnell, A. H, Sunden, A., \& Taylor, C. (2001). What Determines 401(k) Participation and Contributions?, Social Security Bulletin, 64, 64-75. Washington, D.C.: Social Security Administration. http://dx.doi.org/10.2139/ssrn.253037

Perez, S. M. (1998). Efforts to Increase Retirement Savings: Issues for Latino Americans. Working Paper for Senate Special Aging Committee and Employer-Employee Relations Subcommittee of the Workforce Committee. Washington, D.C.: National Council of La Raza.

Purcell, P. J. (2002). Pension Sponsorship and Participation: Trends and Policy Issues. Social Security Bulletin, 64, 92-102. Washington, D.C.: Social Security Administration.

Rogers, G. T. (1982). Private Pension Coverage and Vesting by Race and Hispanic Descent, 1979. Washington, D.C.: U.S. Department of Health and Human Services.

Sana, M. (2005). Buying Membership in the Transnational Community: Migrant Remittances, Social Status, and Assimilation. Population Research and Policy Review, 24, 231-261. http://dx.doi.org/10.1007/s11113-005-4080-7

Santos, R., \& Seitz, P. (2000). Benefit Coverage for Latino and Latina Workers. In Moving Up the Economic Ladder: Latino Workers and the Nation's Future Prosperity. Washington, D.C., National Council of La Raza.

Shuey, K. M., \& O’Rand, A. M. (2004). New Risks for Workers: Pensions, Labor Markets, and Gender. Annual Review of Sociology, 30, 453-477. http://dx.doi.org/10.1146/annurev.soc.30.012703.110534

Shuey, K. M., \& O’Rand, A. M. (2006). Changing Demographics and New Pension Risks. Research on Aging, 28, 317-340. http://dx.doi.org/10.1177/0164027505285919

U.S. Bureau of the Census. (2001). Census 2000 Summary File 4. Washington, D.C.: U.S. Bureau of the Census. http://dx.doi.org/10.3886/icpsr13559.v2

U.S. Bureau of the Census. (2011). Poverty: 2009 and 2010 American Community Survey. Washington, D.C.: U.S. Government Printing Office. 